\title{
Social Contacts of Migrant Women in the Context of Their Linguocultural Orientations (Case of the Republic of Tatarstan)
}

\author{
Tatiana A. Titova and Maria V. Vyatchina* \\ Kazan (Volga region) Federal University \\ 18 Kremliovskaya Str., Kazan, 420008, Russia
}

Received 16.01.2016, received in revised form 21.02.2016, accepted 07.04.2016

The article is devoted to the study of linguocultural competences of migrant women from Central Asia in the Republic of Tatarstan. The analyzed materials were obtained using mass sociological survey methods, as well as biographical and semi-structured interviews. On the basis of language skills in Tatar and Russian languages the article studies attitudes of migrant women to the development of language skills, analyzes different speech situations and reveals the influence of linguocultural competences on the nature of their social contacts, which ultimately determines the success of adaptation in the host society.

Keywords: gender order, lexical reduplication, linguocultural competences, linguistic behaviour, social capital, transnationalism, labour migration.

DOI: 10.17516/1997-1370-2016-9-4-927-931.

Research area: sociology, culture studies.

Labour migration is of exceptional economic, social, political and cultural significance in the modern world. Transport accessibility, development of capitalist relations and open borders have become terms for exercise of the right of each person to freedom of movement and change of their way of life. Today, labour migration is one of the main channels of social mobility. Migration processes occupy a central position on the agenda of the state policy, mass media and scientific symposia. Migration has become not only a part of the everyday and professional lives, but also formed a wide range of topical and problematic issues, the study and solution of which seems promising.

In the perception of the majority, the portrait of an average migrant is drawn exclusively as a man's image. It was widely believed that only men come to earn money, and women are "secondary" or dependent migrants (Tiuriukanova, 2000). That is why migrant women were considered as "invisible workers" for a long time. The study of migrant women is associated with the transformation of the structure of migration flows: if a few years ago it was really mostly men who came for earnings, then, in recent years, the

(C) Siberian Federal University. All rights reserved

* Corresponding author E-mail address: tatiana.titova@rambler.ru, maria.vyatchina@gmail.com 
number of female migrant workers has increased significantly.

According to experts, women account for $25-30 \%$ of migrant workers, which is about $1.5-2$ million people (Ilimbetova, 2013). Mainly, these are people from neighbouring countries and the former USSR: the CIS States dominate in the structure of countries of origin of migrants (about $3 / 4$ of the whole labour migration flow in Russia) (Migrant women, 2011: 16). According to data of the Centre for Migration Studies collected in $2010,30.2 \%$ of women came from Uzbekistan, 9.0\% - from Kazakhstan, 13\% from Kyrgyzstan, 14\% - from China, 13\% from Ukraine. Women who work in Russia belong to the most economically active age group: from age 20 to 50 (Migrant women, 2011: 119). Many studies are devoted to the causes and forms of labour migration of women, as well as its consequences and risks associated with a change of residence and a civil status. Speaking of the difficulties associated with migration of women, researchers are paying particular attention to human trafficking, labour slavery, physical violence, humiliation and discrimination (Korchagin, 2010: 1063). In addition, women leaving their country are faced with problems of loss of career and pension, emotional alienation from relatives and family breakdown (Grishunina, 2011).

Since migration, both labour and female, can be not only in legal, but also in illegal/semilegal forms, its study is complicated: sometimes simple statistical calculation of the number of migrant women and description of their key socio-demographic characteristics (age, marital status, level of education, etc.) are not possible (Chudinovskikh, 2004). Despite the proactive life strategy - a choice in favour of migration, employment, and independent life away from their families - the majority of migrant women, particularly from Central Asia and the Caucasus, have traditional views on family and gender roles. The feminization process of migration flows can be seen as a challenge to the host side, since female migration is accompanied by a number of factors (e.g., a higher proportion of informal employment, ethnic and cultural practices) that may affect the structure of society itself.

The relevance of this issue is due to the need to study the problems associated with the adaptation of labour migrants in the host society, which is of social, economic, political and cultural significance for the modern Russian society in general and the Republic of Tatarstan in particular. The address to the research of migrant women is associated with the fixed process of feminization of migration flows and the increase in the number of migrant women in the total population of the Republic of Tatarstan. There is a growing need to examine the adaptation strategies of migrants, as well as the difficulties associated with entering into a new cultural environment.

This study is based on the methodological principles of the polyparadigmatic approach. In the context of our research there are two basic provisions of the F. Barth's theory: firstly, the conclusion that a determinant for membership in the group become the socially-defined factors that are based on the phenomenon of categorical attribution, but not the "objectively" existing cultural differences. Secondly, ethnic categories, both in the process of identification and classification of others to certain ethnic groups, combine not only the scope of objective differences, but only those that are perceived as significant by individuals themselves.

The work is based on the analysis of empirical materials collected in 2013-2014. Data was collected mainly by methods of observation, semi-structured and biographical interviews. Also the results of the mass survey among women from the communities have been 
involved. Submission of the materials obtained is based on the principles of so-called "thick description", which is an option of the analysis carried out in terms of the informants themselves. The survey interviewed 300 migrant women among the Uzbek, Kyrgyz, Tajik and Azerbaijani population of the Republic of Tatarstan. The analysis also includes 20 interviews with female representatives of Diasporas. The interviewed were divided into two age groups -18-30 (50.7\%) and $31-50$ (49.3\%).

Here are some age and gender characteristics of the respondents. Half of the Kyrgyz participants of the survey are not yet married, $25 \%$ are legally married, and other $25 \%$ are married in the Civil Registry Office and registered by religious laws. The majority of respondents among the Azerbaijani population are married, both according to the law and religious canons. As for the representatives of the Tajik and Uzbek nationality: they are characterized by a relatively larger number of marriages solely on religious grounds. $15 \%$ of Tajik and $25 \%$ Uzbek women confirmed the fact of marriage that was not legally registered. For reference: among the Azerbaijani women the figure is $5 \%$, while among the Kyrgyz women it is zero - none of the respondents said that they are married by religious laws. It should be noted that divorce is not a typical phenomenon for any of the groups surveyed: the number of divorced women do not exceed $5 \%$ in each of the nationalities (Titov, 2014).

From the standpoint of the linguisticcultural competence of respondents, the Uzbek migrants experience the greatest difficulty in adapting to the host society. They show a low level of the Russian language, which, combined with a high level of intra-group consolidation, leads to interaction problems with the host population. The number of migrant women who experience problems in communicating with the local population does not depend on the length of stay in the republic and is almost the same in groups living in the republic for less than 5 years, from 5 to 10 years and more than 10 years, which demonstrates the low adaptive potential among surveyed groups and lack of necessity in inter-ethnic communication. Most migrant women are focused on low-skilled jobs and have no need to improve their linguistic competence in the Russian language. The Azerbaijani women demonstrate more successful adaptation strategies resulting in better knowledge of Russian and Tatar languages, a more pronounced focus on language learning for children, as well as a relatively low level of social distance with members of the local population (the Tatars).

However, speaking about the communicative sphere, we should not be limited only by a choice of language in terms of membership. How the verbal behaviour changes in different contexts (at home, at work, in the market, in public places) and with different interlocutors is also important. This is most clearly manifested in the possibility of observing two or three contact zones in the field study. For example, such a familiar situation for the collector as an interview in the market that intersperses with communication between the informant and customers, neighbours at shopping stalls, friends, etc. provides an excellent opportunity to notice numerous differences. We see how a woman uses a standard set of phrases for communication with customers (to attract attention to a product, to determine clients' needs and, finally, to make the deal). During the conversation with a collector not only the lexicon changes, but also facial expressions, proxemics and a pitch of voice - especially if you can gain the trust. By expecting to return to the conversation you can be involved in an informal friendly conversation that takes place on the basis of bilingual (and sometimes it can be more than two languages) 
and includes humorous phrases, appeals to the context, discussion of the latest news.

Attention to such intricacies as the active use of the word pairs ("shashlyk-mashlyk") or the functioning of rumours (for example, discussion of the Russian lawmakers' plans to tighten the migration regime in the summer of 2014) may be considered by the reader as excessive detailization. Even in case of thick description that, according to a subjective opinion, in a best way reflects the environment of the field study, this attention can be not only a statement of the fact as it is, but also an attempt to implement the cause-and-effect relations. Let us refer to the text of an interview, in which the interlocutor quite actively uses consonances: "analysis-manalysis (analiz-manaliz), they did everything”, "not enough money for powdermowder" (pudra-mudra), "you can buy anything in the store, I'd like onu-manu" (female, 38, Uzbekistan). This phenomenon of lexical reduplication (Lexical reduplication, 2014) with dismissal of linguistic rules may be explained in different ways: as an attempt to learn foreign language faster (let us remember the basics of mnemonics, science of remembering that suggests inventing analogies), as a kind of "infantile" behaviour (indeed, at the stage of language learning our behaviour may resemble a child-like behaviour), as a reflex of the native language introduced into a new one. In reality, in the Turkic languages in the formation of a plural variable component a consonant " $\mathrm{m}$ " is often used (kitap - mitap / book - books, Tur.), which, however, does not prevent the Russianspeaking people say "culture-multure" (kulturmultur).

In conclusion, we can say that migrant women with poor knowledge of Russian and Tatar languages note that in case of the need to interact with the local population, they primarily ask close relatives for help, which indicates the limitation of social contacts of the respondents mostly by a family circle. In turn, it is a result of the gender order stability, where a woman is not considered by the society (neither by the Diaspora, nor by the native population) as the main earner in a family/a source of significant contribution to the family budget, despite the fact that she actually is one.

Despite the declared high level of proficiency in languages of the host population, the majority of the respondents is characterized by focus on communication in the national language, a low level of linguistic competence in relation to the host population languages, and the expressed desire to improve knowledge in the field of Russian and Tatar languages is, to a greater extent, of a declarative nature. The current situation in the linguistic field interferes with successful adaptation of migrant women and creates preconditions for limiting their social contacts by the scope of the ethnic community.

\section{References}

Tiuriukanova, E. (2000). Trudovaia migratsiia zhenshchin iz Rossii: legal'nye i nelegal'nye formy [Labour migration of women from Russia: legal and illegal forms], available at: http: // special.council. gov.ru/activity/analytics/analytical_billeins/25626 (accessed 11 December 2015).

Ilimbetova, A.A. (2013). Zhenshchiny-migranty na rossiiskom rynke truda [Migrant women in the Russian labour market]. In Vestnik Altaiskoi akademii ekonomiki i prava [Bulletin of the Altai Academy of Economics and Law], 2, 25-29.

Tiuriukanova E. (2001). Zhenshchiny-migranty iz stran $S N G v$ Rossii [Female migrants from the CIS countries in Russia]. Moscow, MAKS Press, 119. 
Korchagin, A.G. (2010). Migratsionnaia politika v reshenii migratsionnykh problem v Rossii [Migration policy in dealing with migration issues in Russia], In Pravo i Politika [Law and Politics], 6, 1063-1071.

Grishunina, E.V. (2011). Kognitivno-emotsional'naia struktura perezhivanii slozhnykh zhiznennykh situatsii [Cognitive and emotional structure in experiencing difficult situations], In Konsul'tativnaia psikhologiia i psikhoterapiia [Counseling Psychology and Psychotherapy], 4, 130152.

Chudinovskikh, O. (2004). Prichiny i posledstviia krizisa rossiiskoi migratsionnoi statistiki [Causes and consequences of the Russian migration statistics crisis], In Otechestvennye zapiski [National notes], 4, 176-190.

Leksicheskaia reduplikatsiia. [Lexical reduplication] (2014), available at: http://www.netlore.ru/ shashlyk-mashlyk (accessed 11 December 2015).

Titova, T., E. Frolova, E., Salakhova, A., Garaev, D., Skibo, D., Viatchina, M., Galimullina, A. (2014). Diaspory i soobshchestva migrantov v Respublike Tatarstan: zhenskaia trudovaia migratsiia [Diaspora and migrant communities in the Republic of Tatarstan: female labour migration]. In Etnosotsiologicheskie ocherki [Ethnosociological essays]. Part 2, Kazan, Mir bez granits, 245 p.

\title{
Социальные контакты женщин-мигрантов
}

\section{в контексте их лингвокультурных ориентаций (на примере Республики Татарстан)}

\author{
Т.А. Титова, М.В. Вятчина \\ Казанский (Приволжский) федеральный университет \\ Россия, 420008, Казань, ул. Кремлевская, 18
}

Статья посвящена изучению лингвокультурных компетенций женщин-мигрантов из Центральной Азии в Республике Татарстан. Анализируемые материаль были получень с использованием методов массового сочиологического опроса, а также биографического и полуструктурированного интервью. На основе навыков владения татарским и русским языком рассматриваются установки женщин-мигрантов на развитие языковых навыков, анализируются различные речевые ситуачии, выявляется влияние лингвокультурных компетенций на характер их социальных контактов, что в конечном счете определяет успешность адаптации в принимающем обществе.

Ключевые слова: гендерный порядок, лексическая редупликация, лингвокультурные компетенции, лингвистическое поведение, сочиальный капитал, транснационализм, трудовая мигращия.

Научная специиальность: 22.00.00 - социиологические науки, 24.00.00 - культурология. 